\title{
PENGARUH KUALITAS PELAYANAN, HARGA DAN KEPUASAN KONSUMEN TERHADAP LOYALITAS PELANGGAN DI TIP TOP SWALAYAN PONDOK BAMBU
}

\author{
Imelda Aprileny ${ }^{1}$, Jayanti Apri Emarawati ${ }^{2}$ \\ Sekolah Tinggi Ilmu Ekonomi Indonesia ${ }^{1}$ \\ J1. Kayu Jati Raya No. 11A, Rawamangun - Jakarta 13220, Indonesia ${ }^{1}$ \\ Universitas Persada Indonesia (UPI) $\mathrm{YAI}^{2}$ \\ Jl. Diponogoro 74, Jakarta Pusat ${ }^{2}$ \\ iaprileny@gmail.com ${ }^{1}$, jayantiapri73@gmail.com ${ }^{2}$
}

\begin{abstract}
Abstrak - Penelitian ini bertujuan untuk mengetahui pengaruh kualitas pelayanan, harga dan kepuasan konsumen terhadap loyalitas pelanggan di TIP TOP Swalayan Pondok Bambu. Strategi yang digunakan dalam penelitian ini adalah strategi asosiatif.Metode penelitian ini adalah metode survey yang dilakukan dengan membagikan kuesioner pada konsumen TIP TOP swalayan.. Populasi dalam penelitian ini yaitu seluruh konsumen yang datang dan belanja ke TIP TOP Swalayan Pondok Bambu. Metode sampel yang digunakan adalah purposive sampling,dan sampel dalam penelitian ini berjumlah 97 responden. Metode analisis statistik yang digunakan adalah koefisien determinasi dan uji hipotesis. Berdasarkan hasil pengujian hipotesis dengan taraf nyata 5\% disimpulkan bahwa secara parsial kualitas pelayanan berpengaruh signifikan terhadap loyalitas pelanggan, harga berpengaruh signifikan terhadap loyalitas pelanggan, kepuasan konsumen berpengaruh signifikan terhadap loyalitas pelanggan. Pada hasil hipotesis secara simultan menyimpulkan kualitas pelayanan, harga, dan kepuasan konsumen berpengaruh signifikan terhadap loyalitas pelanggan.
\end{abstract}

Kata kunci : Kualitas Pelayanan, Harga, Kepuasan Konsumen dan Loyalitas Pelanggan

\section{PENDAHULUAN}

\subsection{Masalah Penelitian}

\subsubsection{Latar belakang masalah}

Seiring dengan berkembangnya jaman dari waktu ke waktu, dunia bisnis mengalami perkembangan yang pesat. Semua ini berawal dari kebutuhan konsumen yang beraneka ragam. Sehingga mendorong perusahaan untuk memenuhi kebutuhan konsumen dengan cara menawarkan produk atau jasa yang disesuaikan dengan kebutuhan konsumen dan kemudian mendistribusikannya melalui pasar tradisional dan pasar modern. Persaingan yang sangat ketat di dunia bisnis terjadi pada seluruh jenis 
industri produk maupun jasa. Pelaku bisnis harus mampu memahami kebutuhan dan keinginan konsumen agar dapat bertahan dan memenangkan persaingan.

Begitu pula persaingan yang sangat ketat terjadi pada industri ritel. Bisnis ritel merupakan aktivitas bisnis yang melibatkan penjualan barang dan jasa secara langsung kepada konsumen akhir. Pada perkembangannya, kini bisnis ritel di Indonesia mulai bertransformasi dari bisnis ritel tradisional menuju bisnis ritel modern. Perkembangan bisnis ritel modern di Indonesia semakin meningkat. Hal tersebut dapat dilihat dari munculnya beberapa pelaku bisnis ritel yang membuka cabang di berbagai wilayah di Indonesia seperti Carrefour, Hypermart, Giant, Alfamart, Indomaret dan sebagainya. Semua itu tidak terlepas dari keunggulan-unggulan yang ditawarkan oleh masingmasing pusat perbelanjaan tersebut, misalnya dengan memberikan produk yang bermutu baik, harga lebih murah dan pelayanan yang baik. Hal ini dilakukan agar perusahaan dapat menciptakan loyalitas pelanggan dan menguasai pasar.

Memiliki pelanggan yang loyal adalah salah satu tujuan akhir dari perusahaan. Loyalitas pelanggan menjadi hal penting yang harus diperhatikan, karena loyalitas pelanggan dapat mempertahankan kelangsungan hidup perusahaan dalam jangka panjang. Loyalitas pelanggan adalah komitmen pelanggan terhadap merek, toko, atau pemasok berdasarkan sifat yang sangat positif dalam pembelian jangka panjang ,Tjiptono (2012:21).

Perusahaan yang berhasil bertahan dalam usahanya adalah perusahaan yang mampu memberikan kepuasan kepada konsumen dan pelayanan yang lebih baik dari pesaingnya. Kualitas pelayanan merupakan keseluruhan sifat-sifat dan karakter suatu produk atau jasa berdasarkan kemampuan untuk menyatakan kepuasan atau kebutuhan secara tidak langsung, Kotler dan Keller (2012:145). Apabila pelayanan yang diterima atau dirasakan sesuai dengan yang diharapkan, maka kualitas pelayanan dianggap baik dan memuaskan.

Selain kualitas pelayanan, harga juga termasuk hal penting dalam loyalitas pelanggan. Perusahaan harus mempunyai kelebihan dalam menetapkan harga yang tepat, tentunya perusahaan mengharapkan timbulnya perilaku positif terhadap apa yang ditawarkan. Menurut Swasta (2013:102) harga adalah jumlah uang yang dibebankan atau dikenakan atas sebuah produk atau dengan kata lain harga merupakan sebuah nilai yang harus ditukarkan dengan produk yang dikehendaki konsumen. 
Loyalitas pelanggan juga dapat terbentuk dari kepuasan konsumen yang dirasakan oleh pelanggan. Kepuasan konsumen adalah perasaan senang atau kecewa seseorang yang muncul setelah membandingkan antara kinerja (atau hasil) produk yang dipikirkan terhadap kinerja (atau hasil) yang diharapkan, Kotler dan Keller (2012:177).Sehingga perusahaan perlu menunjukkan nilai tambah untuk memuaskan kebutuhan dan keinginan konsumen. Hal ini dimaksudkan agar konsumen merasa puas dan diharapkan akan berkunjung lagi.

TIP TOP Swalayan merupakan sebuah perusahaan ritel modern dengan format supermarket dan departement store. Berbagai upaya telah dilakukan TIP TOP Swalayan untuk dapat mempertahankan loyalitas pelanggan. Namun pelanggan yang melakukan berbelanja setiap harinya berfluktuatif.

Tabel 1.1 Top Brand Index

\begin{tabular}{|c|c|c|c|c|}
\hline $\begin{array}{c}\text { Kategori } \\
\text { Supermarkat }\end{array}$ & 2013 & 2014 & 2015 & 2016 \\
\hline Hero & $20,7 \%$ & $23,9 \%$ & $22,5 \%$ & $12,2 \%$ \\
\hline Superindo & $11,0 \%$ & $19,1 \%$ & $22,6 \%$ & $15,2 \%$ \\
\hline Tip Top & $7,7 \%$ & $10,0 \%$ & $6,9 \%$ & $7,0 \%$ \\
\hline Griya & $7,2 \%$ & $6,8 \%$ & $6,7 \%$ & $4,4 \%$ \\
\hline ADA & $6,5 \%$ & $6,5 \%$ & $6,5 \%$ & $4,2 \%$ \\
\hline \multicolumn{5}{|c}{ Sumber:Survey Result Top Brand Survey } \\
\hline
\end{tabular}

Berdasarkan Survey Result (Top Brand) diatas terlihat bahwa Tip Top menempati diposisi ke tiga ini dikarenakan pengunjung lebih tertarik berbelanja di supermarket lain seperti Superindo dan Hero. Selain itu TIP TOP Swalayan juga menerima keluhan mengenai ketidaksesuaian produk yang dipesan konsumen ketika delivery order, lalu penataan barang yang kurang sesuai dan kurang rapi, juga kurangnya tanda informasi mengenai kategorisasi barang seperti harga. Maka TIP TOP Swalayan diharapkan untuk menaruh perhatian lebih banyak lagi guna mengurangi keluhan pelanggan tersebut.

Menyadari pentingnya dalam menciptakan loyalitas pelanggan yang berdampak pada kelangsungan hidup perusahaan, maka peneliti tertarik untuk meneliti mengenai Pengaruh Kualitas Pelayanan, Harga dan Kepuasan Konsumen Terhadap Loyalitas Pelanggan di TIP TOP Swalayan Pondok Bambu. 


\subsubsection{Rumusan masalah}

Berdasarkan uraian latar belakang yang tertera diatas, maka dapat dijadikan suatu penelitian dengan "Seberapa besar pengaruh kualitas pelayanan, harga dan kepuasan konsumen terhadap loyalitas pelanggan di TIP TOP Swalayan Pondok Bambu?".

\subsubsection{Spesifikasi masalah}

Maka berdasarkan rumusan masalah diatas dapat dispesifikasi masalah pertanyaan yang dibahas dalam penelitian sebagai berikut:

1. Berapa besar pengaruh kualitas pelayanan terhadap loyalitas pelanggan di TIP TOP Swalayan Pondok Bambu?

2. Berapa besar pengaruh harga terhadap loyalitas pelanggan di TIP TOP Swalayan Pondok Bambu?

3. Berapa besar ada pengaruh kepuasan konsumen terhadap loyalitas pelanggan di TIP TOP Swalayan Pondok Bambu?

4. Berapa besar pengaruh kualitas pelayanan, harga dan kepuasan konsumen secara simultan terhadap loyalitas pelanggan di TIP TOP Swalayan Pondok Bambu?

\subsection{Kerangka Teori}

\subsubsection{Uraian konsepsional tentang variabel}

Menurut Kotler dan Keller (2012:145), kualitas pelayanan merupakan keseluruhan sifat-sifat dan karakter suatu produk atau jasa berdasarkan kemampuan untuk menyatakan kepuasan atau kebutuhan secara tidak langsung.

Menurut Assauri (2012:18) Harga merupakan beban atau nilai bagi konsumen, yang didapatkan dengan memperoleh dan menggunakan suatu produk, termasuk biaya keuangan dari konsumsi, disamping biaya sosial yang bukan keuangan, seperti dalam bentuk waktu, upaya, psikis, risiko dan prestise atau gengsi sosial.

Menurut kotler dan keller (2012:177), Kepuasan konsumen adalah perasaan senang atau kecewa seseorang yang muncul setelah membandingkan antara kinerja (atau hasil) produk yang dipikirkan terhadap kinerja (atau hasil) yang diharapkan.

1. Menurut Tjiptono (2012:21) Loyalitas pelanggan adalah komitmen pelanggan terhadap merek, toko atau pemasok berdasarkan sifat yang sangat positif dalam pembelian jangka panjang. Konsumen dalam menilai kepuasan mengkonsumsi produk adalah umumnya menentukan besarnya harga yang dibeli dengan 
kualitas pelayanan yang diterimanya, yang akhirnya jika konsumen memperoleh kepuasan dalam mengkonsumsi produk maka konsumen akan setia/loyal membeli produk tersebut secara berulang-ulang. Untuk itu perlu bagi TIP TOP swalayan untuk mempertahankan dan meningkatkan hal-hal yang terkait dengan kualitas pelayanan, harga dan kepuasan konsumen agar pelanggan tetap loyal dalam melakukan berbelanja secara rutin.

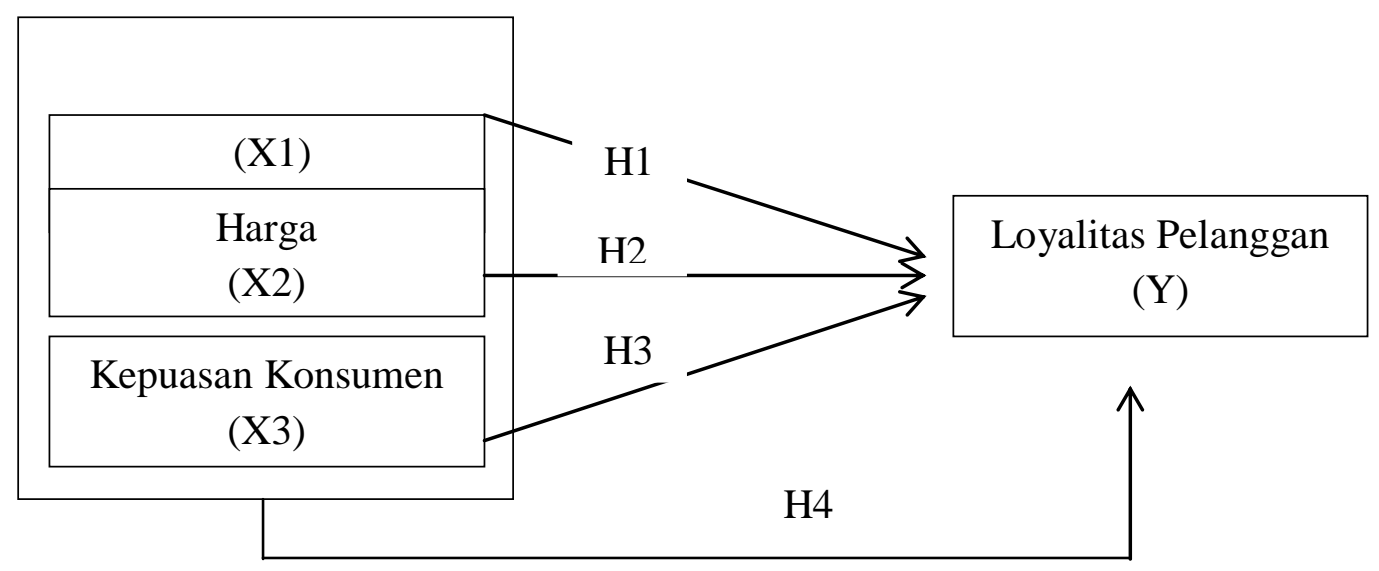

\section{Gambar 1.1 Kerangka Teori}

\subsubsection{Hipotesis penelitian}

Berdasarkan pokok permasalahan diatas dapat dirumuskan hipotesis pada penelitian ini yaitu,

H1 : Diduga terdapat pengaruh kualitas pelayanan terhadap loyalitas pelanggan di TIP TOP Swalayan Pondok Bambu.

H2 : Diduga terdapat pengaruh harga terhadap loyalitas pelanggan di TIP TOP Swalayan Pondok Bambu.

H3 : Diduga terdapat pengaruh kepuasan konsumen terhadap loyalitas pelanggan di TIP TOP Swalayan Pondok Bambu.

H4 : Diduga terdapat pengaruh kualitas pelayanan, harga dan kepuasan konsumen terhadap loyalitas pelanggan di TIP TOP Swalayan Pondok Bambu.

\subsection{Tujuan Penelitian}

Tujuan penelitian ini adalah untuk mengetahui :

1. Pengaruh kualitas pelayanan terhadap loyalitas pelanggan di TIP TOP Swalayan Pondok Bambu. 
2. Pengaruh harga terhadap loyalitas pelanggan di TIP TOP Swalayan Pondok Bambu.

3. Pengaruh kepuasan konsumen terhadap loyalitas pelanggan di TIP TOP Swalayan Pondok Bambu.

4. Pengaruh kualitas pelayanan, harga dan kepuasan konsumen secara simultan terhadap loyalitas pelanggan di TIP TOP Swalayan Pondok Bambu.

\section{PROSEDUR PENELITIAN}

\subsection{Lokasi dan Waktu Penelitian}

Penelitian ini dilakukan di TIP TOP Swalayan Pondok Bambu yang berlokasi di J1. Pahlawan Revolusi No.25, RT.6/RW.12, Pondok Bambu, Duren Sawit, Kota Jakarta Timur. Penelitian ini dilakukan yaitu mulai dari bulan Oktober 2017 sampai dengan Januari 2018.

\subsection{Populasi dan Sample Penelitian}

\subsubsection{Populasi penelitian}

Populasi adalah wilayah generalisasi yang terdiri dari atas: obyek/subyek yang mempunyai kualitas dan karakteristik tertentu yang ditetapkan oleh peneliti untuk dipelajari dan kemudian ditarik kesimpulannya, Menurut Sugiyono (2015:148). Populasi sasaran dalam penelitian ini adalah seluruh konsumen yang datang di TIP TOP Swalayan Pondok Bambu.

\subsubsection{Sampel penelitian}

Menurut Sugiyono (2015:149), sampel adalah bagian dari jumlah dan karakteristik yang dimiliki oleh populasi tersebut. Teknik pengambilan sample dalam penelitian ini dengan Purposive Sampling adalah teknik penentuan sampel dengan pertimbangan tertentu, Menurut Sugiyono (2015:158).

$$
\boldsymbol{n}=\frac{z^{2}}{4(m o e)^{2}}
$$

Keterangan :

$n \quad=$ jumlah sampel

$z=$ nilai $\mathrm{Z}$ dengan tingkat keyakinan tertentu.

Dalam penelitian ini tingkat keyakinan yang digunakan adalah 95\% sehingga nilai $\mathrm{Z}=1,96$ (table distribusi normal) 
moe $=$ margin of error atau kesalahan maksimum yang didapat ditolerir (dalam penelitian ini adalah $10 \%$ )

$$
n=\frac{1,96^{2}}{4(0,1)^{2}}
$$

Maka, jumlah sampel yang diperoleh adalah :

$$
n=96,04 \approx 97
$$

Peneliti mengambil sampel yang ditetapkan sebanyak 97 orang dengan kriteria yang telah berbelanja di TIP TOP Swalayan Pondok Bambu minimal 2 kali, karena jika konsumen sudah pernah berbelanja minimal dua kali berati konsumen tersebut sudah mengetahui keunggulan dan kelemahan pada perusahaan tersebut sehingga data yang diperoleh nantinya dapat lebih akurat mengenai hal yang diteliti.

\subsection{Unit-unit Analisa Penelitian}

Unit analisis dalam penelitian dikelompokan menjadi dua, yang pertama adalah subjek. Subjek dalam penelitian ini adalah konsumen TIP TOP Swalayan Pondok Bambu. Kedua adalah objek, objek dalam penelitian ini adalah kualitas pelayanan (X1), harga (X2), kepuasan konsumen (X3) dan loyalitas pelanggan (Y). Untuk mengetahui data objek dapat dilihat melalui hasil pengisian kuesioner oleh subjek.

\subsection{Metode Pengumpulan Data}

Metode yang dilakukan dalam pengumpulan data penelitian ini yaitu dengan mencari data-data sekunder dan data-data primer.

1. Data sekunder diperoleh dari bacaan, kutipan, dan pengumpulan beberapa teori dari bubu-buku perpustakaan, jurnal, maupun sumber tertulis lainnya yang berkaitan dengan judul penelitian.

2. Data primer diperoleh dengan teknik pengumpulan data yaitu dengan metode survei atau secara langsung melalui observasi yaitu pengamatan secara langsung apa yang menjadi pertimbangan konsumen saat datang di TIP TOP Swalayan Pondok Bambu. Dan dengan kuesioner yaitu pengumpulan data dengan cara mengajukan pertanyaan secara tertulis guna memperoleh tentang tanggapan konsumen terhadap kualitas pelayanan, harga dan kepuasan konsumen terhadap loyalitas pelanggan. 


\subsection{Instrumen Pengumpulan Data}

\subsubsection{Instrumen Penelitian}

Penelitian ini menggunakan 3 variabel independen yaitu kualitas pelayanan (X1), harga (X2) dan kepuasan konsumen (X3) dan 1 variabel dependen yaitu loyalitas pelanggan (Y). Instrumen penelitian ini akan diukur dengan menggunakan Skala Likert, yaitu skala yang digunakan untuk mengukur sikap, pendapat dan persepsi seseorang atau sekelompok orang tentang kejadian tertentu. Instrumen pengumpulan yang digunakan dalam penelitian ini adalah kuesioner. Kuesioner akan dibagikan kepada 97 responden yaitu customer perempuan maupun laki-laki yang datang dan berbelanja di TIP TOP Swalayan Pondok Bambu.

Cara pengumpulan data dengan memberikan daftar pertanyaan tertulis kepada responden dengan harapan mereka akan memberikan jawaban dari pertanyaan tersebut. Dimana jawaban setiap item instrumen mempunyai kategori berkisar antara sangat setuju sampai sangat tidak setuju dan bobot nilai seperti tercantum pada table berikut ini:

\section{HASIL-HASIL PENELITIAN}

\subsection{Deskripsi Obyek Penelitian}

TOP TIP adalah jaringan toko swalayan Islami yang menerapkan cara-cara yang sesuai ajaran Islam dalam kegiatan perdagangannya. Toko swalayan ini memiliki beberapa cabang di Indonesia, terutama di Jakarta, dan menjual lebih dari 200 produk makanan, minuman dan barang kebutuhan hidup lainnya. TIP TOP didirikan pada tahun 1979 oleh Rusman Maamoer. Pada saat ini TIP TOP Supermarket ada di beberapa lokasi, di antaranya: TIP TOP Rawamangun, TIP TOP Cimone, TIP TOP Pondok Bambu, TIP TOP Depok, TIP TOP Ciputat, TIP TOP Pondok Gede, TIP TOP Tambun.

Sejarah perkembangan TIP TOP berawal pada tahun 1979 toko pertama TIP TOP didirikan. Jenis usaha adalah minimarket di kawasan Rawamangun Jakarta timur yang dinamakan TIP TOP Plaza. Tahun 1985 memperluas jenis usaha dari minimarket menjadi supermarket \& Dept. Store dengan dilengkapi arena bermain anak. Ketika tahun 1991 bulan Juni Outlet TIP TOP Rawamangun terbakar habis lalu dibuka kembali Outlet TIP TOP Rawamangun pada bulan Oktober. Setelah itu tahun 1992 membuka outlet kedua di daerah Ciputat, Tangerang. Tahun 1999 membuka outlet ketiga di daerah Perumahan Taman Cibodas,sektor Cimone, Tangerang. Tahun 2001 membuka 
outlet keempat di daerah Pondok Bambu, Jakarta Timur. Tahun 2004 membuka outlet kelima di daerah Depok, Jawa Barat. Tahun 2007 membuka outlet keenam di daerah Pondok Gede, Bekasi. Lalu di tahun 2011 Outlet TIP TOP Ciputat pindah lokasi ke Jalan R.E.Martadinata No.5 ,Ciputat. Dan pada tahun 2014 membuka outlet ketujuh di daerah Tambun Selatan, Bekasi. Adapun visi dan misi TIP TOP adalah sebagai berikut : Visi:

Berguna bagi banyak orang

Misi:

- Memuaskan hati orang banyak dengan menjalankan sistem usaha yang Islami.

- Menyediakan barang dengan harga murah.

- Menyatukan kekuatan untuk menjadi yang terdepan / terbaik di bidangnya. TIP TOP memiliki komitmen sebagai berikut:

- Menyediakan barang-barang kebutuhan Anda dengan harga murah dan bersaing.

- Menyediakan produk yang beraneka ragam dan berkualitas tinggi.

- Hanya menyediakan barang-barang halal.

- Memberikan harga-harga promosi untuk bermacam-macam produk setiap bulan.

- Melayani pelanggan kami sebaik mungkin.

- Menjadikan TIP TOP menjadi toko yang Anda percayai dan senangi sepanjang masa.

Layanan pembayaran di TIP TOP menerima pembayaran dengan Kartu Kredit / Debit: Visa, Master Card, Sodexo Gift Pass, Debit BCA, BCA Card, Visa Electron, Maestro, American Express. Semua transkasi pembayaran tidak dikenakan biaya tambahan.

Ragam Produk TIP TOP menyediakan keperluan harian Anda selengkap dan semurah mungkin. Untuk menambah keanekaragaman produk, disamping menjual kebutuhan rumah tangga Anda, TIP TOP juga menyediakan kebutuhan busana, elektronik, pecah belah, olah raga dan furniture. Bagi pengunjung yang sudah berkeluarga, Anda bisa leluasa berbelanja karena TIP TOP menyediakan arena bermain anak-anak seperti bumper car, kuda-kudaan, dan masih banyak lagi sehingga Anda bisa leluasa berberlanja sambil anak-anak Anda bermain. 


\subsection{Deskripsi Responden}

Deskripsi identitas responden penelitian berdasarkan jenis kelamin, usia, dan pekerjaan.

1. Jenis Kelamin

Gambar Pie 4.1. Deskripsi responden berdasarkan jenis kelamin

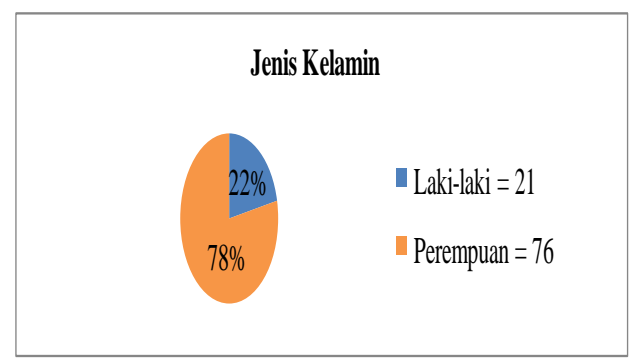

Sumber : Data diolah 2017

Berdasarkan GambarPie 4.1. sebagian besar responden yang datang ke TIP TOP Pondok Bambu berjenis kelamin perempuan yaitu sebanyak 76 orang (78\%), karena perempuan lebih suka menyempatkan waktu untuk berbelanja dan perempuan lebih peka terhadap persediaan kebutuhan keluarga untuk sehari-hari.

2. Usia

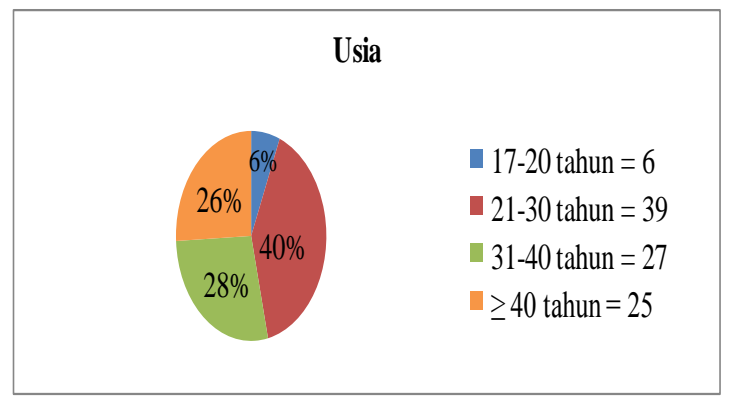

Gambar Pie 4.2. Deskripsi responden berdasarkan usia Sumber : Data diolah, 2017

Berdasarkan GambarPie 4.2. sebagian besar responden yang datang ke TIP TOP Pondok Bambuberusia 21-30 tahun yaitu sebanyak 39 orang (40\%), karena di usia tersebut merupakan usia yang produktif kuat (jiwa muda) dalam melakukan berbelanja untuk memilih-milih kebutuhan apa saja yang diperlukan. 
3. Pekerjaan

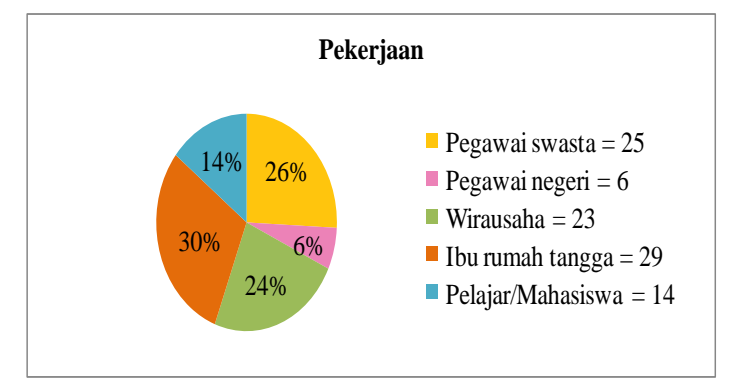

Gambar Pie 4.3. Deskripsi responden berdasarkan pekerjaan Sumber : Data diolah, 2017

Berdasarkan GambarPie 4.3. sebagian besar responden yang datang ke TIP TOP Pondok Bambu adalah ibu rumah tangga yaitu sebanyak 29 orang (30\%), karena seorang ibu rumah tangga memiliki tugas untuk mengelola keuangan dalam menentukan persediaan kebutuhan keluarga sehari-hari dan ibu rumah tangga memiliki banyak kebutuhan untuk keluarga.

Dengan demikian dapat disimpulkan bahwa sebagian besar responden yang datang berbelanja di TIP TOP Pondok Bambu adalah perempuan seorang ibu rumah tangga berusia 21-30 tahun.

\subsection{Deskripsi Data}

Tanggapan responden terhadap indikator dan perhitungan kuesioner variabel dapat dilihat dan digambarkan dalam diagram Skala Likert. Variabel yang digunakan dalam penelitian ini yaitu variabel kualitas pelayanan $\left(\mathrm{X}_{1}\right)$, harga $\left(\mathrm{X}_{2}\right)$, kepuasan konsumen $\left(\mathrm{X}_{3}\right)$ dan loyalitas pelanggan $(\mathrm{Y})$. Data yang digunakan dalam penelitian ini adalah hasil dari pengisian kuesioner oleh responden TIP TOP Pondok Bambu sebanyak 97 orang.

Variabel kualitas pelayanan $\left(\mathrm{X}_{1}\right)$ yang telah diberikan kepada 97 responden, dapat memperoleh hasil $X_{1}=10 \times 97 \times 4=3880$.Jumlah skor dari pengumpulan data adalah 3068. Maka kualitas pelayanan menurut responden adalah $3068: 3880=79.07 \%$. Hasil tersebut dapat digambarkan sebagai berikut:

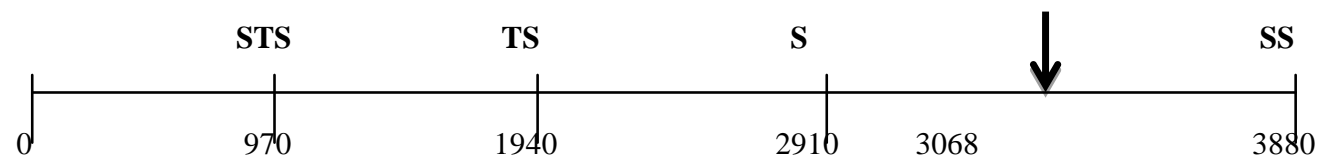

Gambar 4.4 Diagram Skala Likert variabel kualitas pelayanan

Variabel kualitas pelayanan dapat disimpulkan bahwa jawaban dari responden berada di daerah sangat setuju. 
Variabel harga $\left(\mathrm{X}_{2}\right)$ yang telah diberikan kepada 97 responden, sehingga dapat memperoleh hasil $\mathrm{X}_{2}=3 \times 97 \times 4=1164$.Jumlah skor dari pengumpulan data adalah 947. Maka harga menurut responden adalah947:1164 =81,36\%. Hasil tersebut dapat digambarkan sebagai berikut:

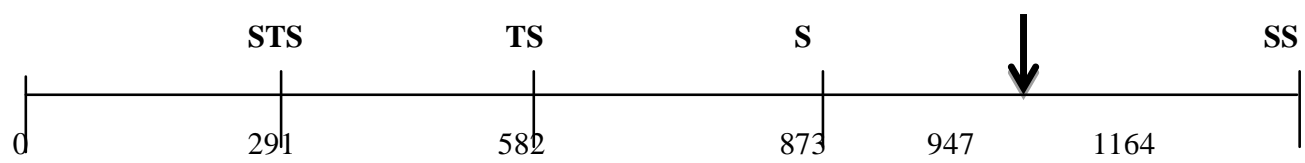

Gambar 4.5 Diagram Skala Likert variabel harga dapat disimpulkan bahwa jawaban dari responden berada di daerah sangat setuju.

Variabel kepuasan konsumen $\left(\mathrm{X}_{3}\right)$ yang telah diberikan kepada 97 responden, sehingga dapat memperoleh hasil $\mathrm{X}_{3}=5$ x 97 x $4=1940$.Jumlah skor dari pengumpulan data adalah 1545. Maka kepuasan konsumen menurut responden adalah1545:1940= 79,64\%. Hasil tersebut dapat digambarkan sebagai berikut:

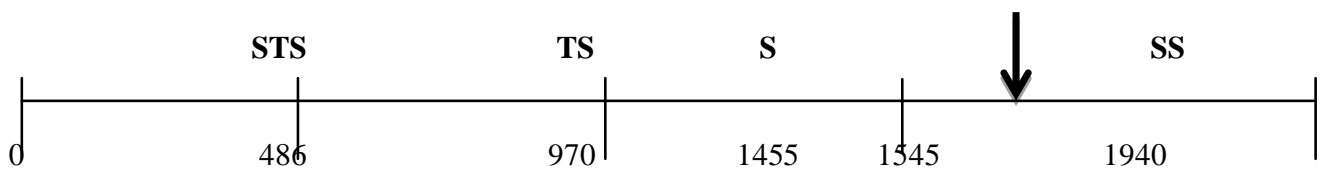

Gambar 4.6 Diagram Skala Likert variabel kepuasan konsumen dapat disimpulkan bahwa jawaban dari responden berada di daerah sangat setuju.

Variabel loyalitas pelanggan (Y) yang telah diberikan kepada 97 responden, sehingga dapat memperoleh hasil $\mathrm{Y}=4$ x 97 x $4=1552$. Jumlah skor dari pengumpulan data adalah 1244. Maka loyalitas pelanggan menurut responden adalah1244 :1552= $80,15 \%$. Hasil tersebut dapat digambarkan sebagai berikut:

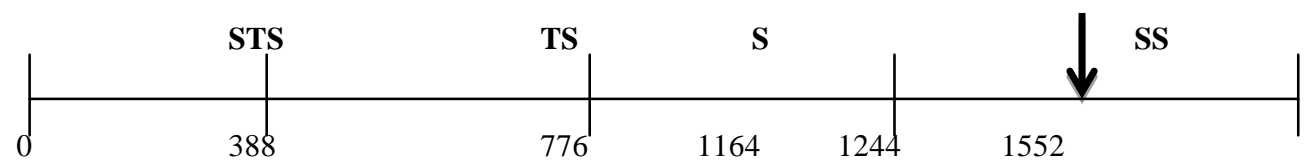

Gambar 4.7 Diagram Skala Likert variabel loyalitas pelanggan dapat disimpulkan bahwa jawaban dari responden berada di daerah sangat setuju.

\subsection{Hasil Pengujian Instrumen Penelitian}

\subsubsection{Uji validitas}

Setelah melakukan pengumpulan data dari responden maka selanjutnya melakukan uji validitas. Instrument penelitian dikatakan valid atau akurat apabila memiliki nilai validitas lebih dari 0,30 dan jika nilai validitas kurang dari 0,30 maka 
dapat dikatakan tidak valid atau tidak akurat. Uji validitas ini dihitung menggunakan program SPSS 22.

Berdasarkan hasil uji validitas untuk seluruh variabel penelitian maka dapat disimpulkan bahwa instrumen kualitas pelayanan $\left(\mathrm{X}_{1}\right)$, harga $\left(\mathrm{X}_{2}\right)$, dan kepuasan konsumen $\left(\mathrm{X}_{3}\right)$ maupun loyalitas pelanggan $(\mathrm{Y})$ dinyatakan reliabel karena menunjukkan nilai $r$ hit $>$ r kritis $(0,30)$.

\subsubsection{Uji Reliabilitas}

Setelah melakukan uji validitas, maka untuk pernyataan yang valid selanjutnya dilakukan pengujian reliabilitas. Uji reliabilitas menggunakan metode split half dengan rumus spearman brown dimana instrumen dapat dikatakan reliabel apabila memiliki koefisien 0,60 atau lebih.

Berdasarkan hasil uji reliabilitas untuk seluruh variabel penelitian maka dapat disimpulkan bahwa instrumen kualitas pelayanan $\left(\mathrm{X}_{1}\right)$, harga $\left(\mathrm{X}_{2}\right)$, dan kepuasan konsumen $\left(\mathrm{X}_{3}\right)$ maupun loyalitas pelanggan $(\mathrm{Y})$ dinyatakan reliabel karena menunjukkan nilai $\mathrm{r}_{\mathrm{i}}>0,60$.

\subsection{Analisis Statistik Data}

\subsubsection{Analisis koefisien determinasi (KD)}

\subsubsection{Koefisien determinasi parsial}

1. Koefisien determinasi parsial kualitas pelayanan $\left(\mathrm{X}_{1}\right)$ terhadap loyalitas pelanggan $(\mathrm{Y})$

Berdasarkan dengan hasil pengolahan data menggunakan SPSS (Lampiran 18) diperoleh hasil koefisien korelasi parsial antara $\mathrm{X}_{1}$ dengan Y sebesar 0,243.

Hasil koefisien determinasi parsial kualitas pelayanan terhadap loyalitas pelanggan sebesar $5,91 \%$. Sehingga dapat diinterprestasikan bahwa pengaruh kualitas pelayanan terhadap loyalitas pelanggan sebesar 5,91\% dan sisanya sebesar 94,09\% dipengaruhi oleh variabel lain.

2. Koefisien determinasi parsial harga $\left(\mathrm{X}_{2}\right)$ terhadap loyalitas pelanggan (Y) 
Berdasarkan dengan hasil pengolahan data menggunakan SPSS (Lampiran 18) diperoleh hasil koefisien korelasi parsial antara $\mathrm{X}_{2}$ dengan Y sebesar 0,229.

Hasil koefisien determinasi parsial harga terhadap loyalitas pelanggan sebesar 5,24\%. Sehingga dapat diinterprestasikan bahwa pengaruh harga terhadap loyalitas pelanggan sebesar 5,24\% dan sisanya sebesar 94,76\% dipengaruhi oleh variabel lain.

3. Koefisien determinasi parsial kepuasan konsumen $\left(\mathrm{X}_{3}\right)$ terhadap loyalitas pelanggan $(\mathrm{Y})$

Berdasarkan dengan hasil pengolahan data menggunakan SPSS (Lampiran 18) diperoleh hasil koefisien korelasi parsial antara $\mathrm{X}_{3}$ dengan Y sebesar 0,322 .

Hasil koefisien determinasi parsial kepuasan konsumen terhadap loyalitas pelanggan sebesar $10,37 \%$. Sehingga dapat diinterprestasikan bahwa pengaruh kepuasan konsumen terhadap loyalitas pelanggan sebesar 10,37\% dan sisanya sebesar 89,63 dipengaruhi oleh variabel lain.

\subsubsection{Koefisien determinasi berganda (Simultan)}

Koefisien determinasi berganda digunakan untuk mengetahui tingkat keeratan pengaruh antara kualitas pelayanan, harga, dan kepuasan konsumen terhadap loyalitas pelanggan.Penelitian ini menggunakan rumus product moment sehingga mendapatkan data berpasangan antara $X_{1}, X_{2}, X_{3}$, dan $Y$ (lampiran 19). Setelah melakukan pengolahan data menggunakan SPSS 22 maka diperoleh nilai koefisien determinasi berganda sebagai berikut :

$$
\begin{aligned}
\mathrm{KD}_{1.2 .3} & =\mathrm{r}_{\mathrm{Y} 123}{ }^{2} \times 100 \% \\
& =(0,388) \times 100 \% \\
& =38,8 \%
\end{aligned}
$$

Hasil koefisien determinasi bergandakualitas pelayanan, harga dan kepuasan konsumen terhadap loyalitas pelanggan sebesar $38.8 \%$. Sehingga dapat diinterprestasikan bahwa pengaruh kualitas pelayanan, 
harga dan kepuasan konsumen terhadap loyalitas pelanggan sebesar $38.8 \%$ dan sisanya sebesar $61.2 \%$ dipengaruhi oleh variabel lain.

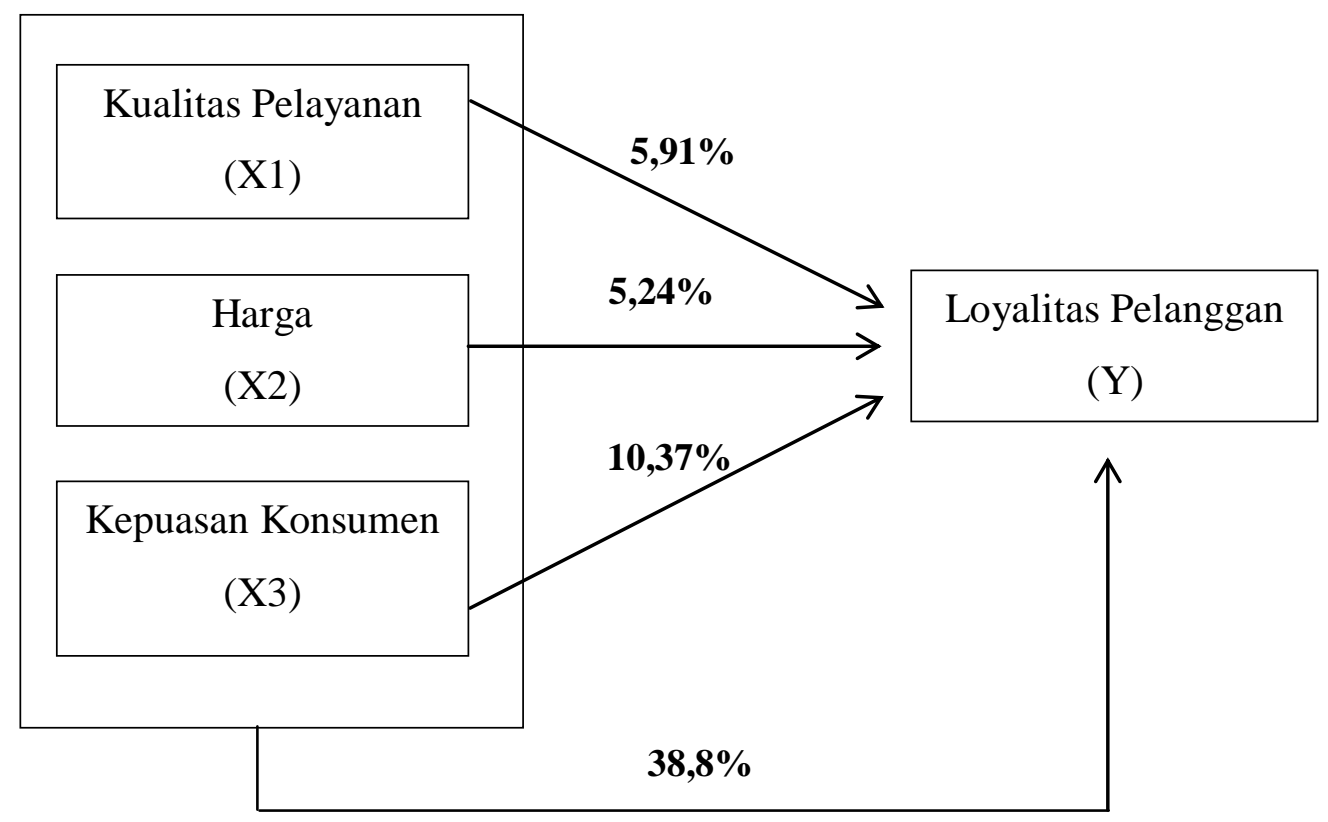

\section{Gambar 4.8 Hasil Koefisien Determinasi Parsial dan Simultan}

\subsection{Uji Hipotesis}

\subsubsection{Pengujian Hipotesis}

\section{Pengujian hipotesis secara parsial (Uji t)}

a. Pengaruh kualitas pelayanan $\left(\mathrm{X}_{1}\right)$ terhadap loyalitas pelanggan $(\mathrm{Y})$

Berdasarkan hasil pengolahan data menggunakan SPSS di (Lampiran 19) diperoleh signifikantsebesar 0,018. Dapat disimpulkan $H_{o}$ ditolak dan $\mathrm{H}_{\mathrm{a}}$ diterima, karena nilaisignifikant lebih kecil dari taraf nyata $\alpha=$ $5 \%$ atau $(0,018)<0,05$, maka secara parsial terdapat pengaruh yang signifikan antara kualitas pelayanandengan loyalitas pelanggan.

b. Pengaruh harga $\left(\mathrm{X}_{2}\right)$ terhadap loyalitas pelanggan $(\mathrm{Y})$

Berdasarkan hasil pengolahan data menggunakan SPSS di (Lampiran 19) diperoleh signifikan $t$ sebesar 0,026 . Dapat disimpulkan $H_{o}$ ditolak dan $\mathrm{H}_{\mathrm{a}}$ diterima, karena nilai signifikan $t$ lebih kecil dari taraf nyata $\alpha=5 \%$ atau $(0,026)<0,05$, maka secara parsial terdapat pengaruh yang signifikan antara harga dengan loyalitas pelanggan.

c. Pengaruh kepuasan konsumen $\left(\mathrm{X}_{3}\right)$ terhadap loyalitas pelanggan $(\mathrm{Y})$ 
Berdasarkan hasil pengolahan data menggunakan SPSS di (Lampiran 19) diperoleh signifikan $t$ sebesar 0,001 . Dapat disimpulkan $H_{o}$ ditolak dan $\mathrm{H}_{\mathrm{a}}$ diterima karena signifikan $t$ lebih kecil dari taraf nyata $\alpha=$ $5 \%$ atau $(0,001)<0,05$, maka secara parsial terdapat pengaruh yang signifikan antara kepuasan konsumen dengan loyalitas pelanggan.

\section{Pengujian hipotesis secara simultan (Uji F)}

Berdasarkan hasil pengolahan data menggunakan SPSS di (Lampiran 19) diperoleh signifikanF sebesar 0,000. Dapat disimpulkan $\mathrm{H}_{\mathrm{o}}$ ditolak dan $\mathrm{H}_{\mathrm{a}}$ diterima, karena signifikan $\mathrm{F}$ lebih kecil dari taraf nyata $\alpha=5 \%$ atau $(0,000)<0,05$, maka secara simultan terdapat pengaruh yang signifikan antara kualitas pelayanan, harga dan kepuasan konsumen terhadap loyalitas pelanggan.

\section{KESIMPULAN DAN SARAN}

\subsection{Kesimpulan}

Berdasarkan dari hasil penelitian yang telah diuraikan pada bab sebelumnya, maka dapat disimpulkan bahwa hasil penelitiannya sebagai berikut:

1. Secara parsial hasil penelitian di TIP TOP Swalayan Pondok Bambu, menunjukkan bahwa variabel kualitas pelayanan memiliki pengaruh sebesar 5,91\% terhadap loyalitas pelanggan.

2. Secara parsial hasil penelitian di TIP TOP Swalayan Pondok Bambu, menunjukkan bahwa variabel harga memiliki pengaruh sebesar 5,24\% terhadap loyalitas pelanggan.

3. Secara parsial hasil penelitian di TIP TOP Swalayan Pondok Bambu, menunjukkan bahwa variabel kepuasan konsumen memiliki pengaruh sebesar 10,37\% terhadap loyalitas pelanggan.

4. Secara simultan hasil penelitian di TIP TOP Swalayan Pondok Bambu, menunjukkan bahwa variabel kualitas pelayanan, harga dan kepuasan konsumen memiliki pengaruh sebesar 38,8\% terhadap loyalitas pelanggan.

5. Pengujian hipotesis dengan taraf nyata 5\% dapat disimpulkan bahwa secara parsial variabel kualitas pelayanan berpengaruh signifikan terhadap loyalitas pelanggan, variabel harga berpengaruh signifikan terhadap loyalitas pelanggan dan variabel kepuasan konsumen berpengaruh signifikan terhadap loyalitas pelanggan. 
Berdasarkan hasil pengujian hipotesis secara simultan maka variabel kualitas pelayanan, harga dan kepuasan konsumen berpengaruh signifikan terhadap loyalitas pelanggan. Dari hasil pengujian hipotesis menunjukkan bahwa variabel kepuasan konsumen memiliki pengaruh yang paling dominan.

\subsection{Saran}

Berdasarkan dari hasil kesimpulan diatas, maka dapat diberikan saran yang dapat dijadikan sebagai bahan pertimbangan bagi perusahaan. Hal-hal yang disarankan sebagai berikut:

1. Berdasarkan hasil kuesioner yeng terendah dari Harga, maka diharapkan TIP TOP Swalayan Pondok Bambu perlu untuk fokus terhadap kebijakan menetapkan harga yang tepat sesuai dengan keinginan pelanggan. Misalnya dengan selalu memantau perubahan harga yang ditetapkan oleh pesaing, agar harga yang ditetapkan di TIP TOP tidak terlalu mahal namun relatif lebih murah dari pesaing lainnya. Selain itu juga dapat dilakukan dengan memperbanyak program promosi terkait dengan harga agar konsumen tertarik seperti memberikan hadiah, potongan harga dan promo buy 1 get 1 . Sehingga pelanggan akantetap loyal dalam melakukan berbelanja di TIP TOP Swalayan Pondok Bambu.

2. Berdasarkan hasil kuesioner yeng terendah dari kualitas pelayanan, maka diharapkan TIP TOP Swalayan Pondok Bambu terus meningkatkan kualitas pelayanan yang ada sehingga pelanggan akan tetap menjalin hubungan baik dengan perusahaan dimasa mendatang dan akan tetap terciptanya loyalitas pelanggan.

3. Berdasarkan hasil kuesioner yeng terendah dari loayalitas pelanggan, maka diharapkan TIP TOP Swalayan Pondok Bambu perlu untuk mempertahankan dan meningkatkan hal-hal yang terkait dengan kualitas pelayanan, harga dan kepuasan konsumen agar pelanggan tetap loyal dalam melakukan berbelanja secara rutin.

\section{DAFTAR PUSTAKA}

Assauri, Sofjan. 2012. Manajemen Pemasaran. PT. Raja Grafindo Persada. Jakarta Buchory, Herry Achmad dan Djaslim Saladin. 2012. Manajemen Pemasaran. Linda Karya. Bandung 
Ghozali, Imam. 2012. Aplikasi Analisis Multivariate dengan Program IBM SPSS. Badan Penerbit Universitas Diponegoro. Semarang

Hurriyati, Ratih. 2015. Bauran Pemasaran dan Loyalitas Konsumen.Alfabetha. Bandung

Kotler, Philip dan Kevin Lane Keller. 2012. Manajemen Pemasaran. Jilid.I Edisi.Ketigabelas.Erlangga. Jakarta

2012. Manajemen Pemasaran.Jilid. II

Edisi. Ketigabelas.Erlangga. Jakarta dan Gary Armstrong. 2012. Prinsip-prinsip Pemasaran. Jilid.I Edisi. 13.

Erlangga. Jakarta

Swasta, Basu dan Irawan. 2013. Manajemen Pemasaran Modern. Liberty. Yogyakarta

Sugiyono. 2015. Metode Penelitian Manajemen, Pendekatan Kuantitatif, Kualitatif dan $R \& D$. Alfabeta. Bandung 2016. Metode Penelitian Kuantitatif, Kualitatif dan R\&D. Alfabeta. Bandung

Sunyoto, Danang. 2015. Perilaku Konsumen dan Pemasaran.CAPS. Yogyakarta

Tjiptono, Fandy. 2012. Service Management, Meningkatkan Layanan Prima. ANDI. Jakarta

. 2012. Strategi Pemasaran. Edisi kedua.ANDI. Yogyakarta dan Anastasia Diana. 2015. Pelanggan puas? Tak Cukup. CV. ANDI. Yogyakarta

Whidya, Utami Christina. 2012. Manajemen Ritel, Strategi dan Implementasi Ritel Modern. Salemba Empat. Jakarta 